\title{
Biomechanical signals and the C-type natriuretic peptide counteract catabolic activities induced by IL-1 $\beta$ in chondrocyte/agarose constructs
}

\author{
Manoj Ramachandran², Prim Achan², Donald M Salter ${ }^{3}$, Dan L Bader ${ }^{1}$ and Tina T Chowdhury ${ }^{1 *}$
}

\begin{abstract}
Introduction: The present study examined the effect of C-type natriuretic peptide (CNP) on the anabolic and catabolic activities in chondrocyte/agarose constructs subjected to dynamic compression.

Methods: Constructs were cultured under free-swelling conditions or subjected to dynamic compression with low (0.1 to $100 \mathrm{pM}$ ) or high concentrations (1 to 1,000 nM) of CNP, interleukin-1 $\beta$ (IL-1 $\beta$ ), and/or KT-5823 (inhibits cyclic GMP-dependent protein kinase II (PKGII)). Anabolic and catabolic activities were assessed as follows: nitric oxide (NO) and prostaglandin $\mathrm{E}_{2}\left(\mathrm{PGE}_{2}\right)$ release, and $\left[{ }^{3} \mathrm{H}\right]$-thymidine and ${ }^{35} \mathrm{SO}_{4}$ incorporation were quantified by using biochemical assays. Gene expression of inducible nitric oxide synthase (iNOS), cyclooxygenase-2 (COX-2), aggrecan, and collagen type II were assessed with real-time quantitative PCR (qPCR). Two-way ANOVA and the post hoc Bonferroni-corrected $t$ tests were used to examine data.
\end{abstract}

Results: CNP reduced $\mathrm{NO}$ and $\mathrm{PGE}_{2}$ release and partially restored $\left[{ }^{3} \mathrm{H}\right]$-thymidine and ${ }^{35} \mathrm{SO}_{4}$ incorporation in constructs cultured with IL-1 $1 \beta$. The response was dependent on the concentration of CNP, such that $100 \mathrm{pM}$ increased $\left[{ }^{3} \mathrm{H}\right]$-thymidine incorporation $(P<0.001)$. This is in contrast to ${ }^{35} \mathrm{SO}_{4}$ incorporation, which was enhanced with 100 or $1000 \mathrm{nM} C N P$ in the presence and absence of $\mathrm{IL}-1 \beta(P<0.001)$. Stimulation by both dynamic compression and CNP and/or the PKGIl inhibitor further reduced $\mathrm{NO}$ and $\mathrm{PGE}_{2}$ release and restored $\left.{ }^{3} \mathrm{H}\right]$-thymidine and ${ }^{35} \mathrm{SO}_{4}$ incorporation. In the presence and absence of $\mathrm{IL}-1 \beta$, the magnitude of stimulation for $\left[{ }^{3} \mathrm{H}\right]$-thymidine and ${ }^{35} \mathrm{SO}_{4}$ incorporation by dynamic compression was dependent on the concentration of CNP and the response was inhibited with the PKGII inhibitor. In addition, stimulation by CNP and/or dynamic compression reduced IL-1 $\beta$ induced $\mathrm{NOS}$ and COX-2 expression and restored aggrecan and collagen type II expression. The catabolic response was not further influenced with the PKGII inhibitor in IL-1 $\beta$-treated constructs.

Conclusions: Treatment with CNP and dynamic compression increased anabolic activities and blocked catabolic effects induced by IL-1 $1 \beta$. The anabolic response was PKGII mediated and raises important questions about the molecular mechanisms of CNP with mechanical signals in cartilage. Therapeutic agents like CNP could be administered in conjunction with controlled exercise therapy to slow the OA disease progression and to repair damaged cartilage. The findings from this research provide the potential for developing novel agents to slow the pathophysiologic mechanisms and to treat $O A$ in the young and old.

\section{Introduction}

In healthy cartilage, chondrocytes mediate matrix remodelling through a balance in the synthesis and degradation of the extracellular matrix components. This constant process is regulated by transient autocrine and

\footnotetext{
* Correspondence: t.t.chowdhury@qmul.ac.uk

'School of Engineering and Materials Science, Queen Mary University of London, Mile End Road, London E1 4NS, UK

Full list of author information is available at the end of the article
}

paracrine factors, which act through common pathways, involving cytokines, signaling molecules, kinases, and transcription factors, each of which is additionally influenced by mechanical signals [1-6]. However, aging or injury to the joint may trigger mechanical overload and influence these pathways, leading to matrix damage and osteoarthritis (OA) $[7,8]$. The identification of the signals that are activated during the different stages of the disease process is highly challenging and involves

\section{Biomed Central}


examination of both molecular and mechanical factors. To date, no successful chondroprotective or diseasemodifying therapies are available to intervene in this pathological cycle and help to restore joint function. Thus, agents for promoting biophysical and therapeutic strategies to slow the pathophysiologic mechanisms and treat $\mathrm{OA}$ are under active investigation.

As an example, the C-type natriuretic peptide (CNP) has recently emerged as an important anabolic regulator of cartilage [9-11]. Indeed, stimulation of chondrocytes with CNP has been reported to increase collagen and proteoglycan synthesis and to enhance cell proliferation [12-14]. Moreover, the guanylyl cyclase B and intracellular 3,5'-cyclic guanosine monophosphate (GC-B/cGMP) pathway was shown to mediate the increase of cell proliferation in rat chondrocytes treated with CNP $[15,16]$. Upregulation of the GC-B/cGMP system by CNP is essential for cartilage development and involves cyclic GMP-dependent protein kinase II (PKGII) mechanisms in late proliferative and pre-hypertrophic zones of growth-plate cartilage [9,17-19]. Indeed, targeted disruption of the genes encoding CNP and PKGII results in impaired growth of endochondral bones and leads to severe dwarfism and skeletal defects $[9,17,18]$. Conversely, overexpression of CNP results in skeletal overgrowth and rescued dwarfism in a murine model of human achondroplasia [20]. Consequently, growing evidence suggests that stimulation of CNP signaling may contribute to anabolic events and potentially provide a new therapeutic application for conditions with loss of cartilage matrix and in the treatment of skeletal growth disorders.

Numerous studies have shown that chondrocytes from many species produce nitric oxide (NO) and prostaglandin $E_{2}\left(P_{G} E_{2}\right)$ release, via induction of the inducible nitric oxide synthase (iNOS) and cyclooxygenase (COX2 ) enzymes, in response to interleukin-1 $\beta$ (IL-1 $\beta$ ) and tumor necrosis factor alpha (TNF- $\alpha$ ) [21-24]. These pro-inflammatory cytokines are involved in the pathogenesis of $\mathrm{OA}$, but their regulation by mechanical signals is necessarily complex. For example, in vitro mechanical conditioning experiments demonstrate that mechanical signals, representing a controlled physiological activity, inhibit IL- $1 \beta$-induced iNOS and COX-2 expression and restore matrix synthesis $[25,26]$. The opposite effect was found for mechanical signals, which could be interpreted as an excessive or injurious response, and enhanced the IL-1 $\beta$-induced catabolic response [27]. These findings indicate that mechanical signals that mimic the physiological loading environment of cartilage act in an anti-inflammatory manner and could therefore provide a physical strategy to repair damaged tissue $[28,29]$. Our data concur with clinical findings that demonstrate the beneficial effects of prescribed rehabilitative therapies for reducing inflammation and improving joint function in patients with knee OA [30-32]. However, no agreement has been achieved on whether controlled exercise therapy could be efficacious in the aging population [33]. Consequently, restoration of chondrocyte function with CNP in combination with physical therapies may promote cartilage health in the OA joint.

These observations raise the possibility for the potential therapeutic effects of both CNP and mechanical stimuli in reducing the cytokine-induced catabolic events in OA. However, very little is known about the molecular mechanisms activated by CNP and their role in stimulating matrix production in OA chondrocytes. No studies have investigated the interactions of mechanical loading with the CNP pathway or whether they compete with catabolic pathways induced by cytokines. The present study therefore examines the effect of CNP and mechanical loading on anabolic and catabolic activities in chondrocyte/agarose constructs stimulated with IL$1 \beta$.

\section{Materials and methods}

\section{Chondrocyte isolation and culture in agarose constructs}

Human cartilage was obtained from nine patients (age 35 to 58 years), with ethical approval (East London and The City Research Ethics Committee) and informed patient consent, undergoing total knee arthroplasty at the Royal London Hospital, Barts, and the London NHS Trust, London, UK. Cartilage was removed from the femoral condyles and tibial plateaus. The morphology of the cartilage specimens was graded for gross degenerative changes according to the ICRS classification, and tissues that represent normal (grade 0 or 1 ) and early (grade 2) OA were used for experiments. Each experimental condition was repeated with chondrocytes from three to four different donors. Cartilage tissue was diced and incubated on rollers for 1 hour at $37^{\circ} \mathrm{C}$ in Dulbecco Modified Eagle Medium (DMEM) supplemented with $10 \%$ (vol/vol) Fetal Calf Serum (FCS) $+2 \mu M$ L-glutamine, $5 \mu \mathrm{g} / \mathrm{ml}$ penicillin, $5 \mu \mathrm{g} / \mathrm{ml}$ streptomycin, $20 \mathrm{mM}$ Hepes buffer, and $0.05 \mathrm{mg} / \mathrm{ml} \mathrm{L-ascorbic} \mathrm{acid}+700$ unit $/ \mathrm{ml}$ pronase and incubated for a further 16 hours at $37^{\circ} \mathrm{C}$ in DMEM $+10 \%$ FCS, supplemented with 100 units/ml collagenase type XI (Sigma-Aldrich, Poole, UK). The cell suspension was washed and viable chondrocytes counted using a hemocytometer and trypan blue. Cells were finally resuspended in medium at a cell concentration of $8 \times 10^{6}$ cells/ml by using well-established methods [34,35]. In brief, the cell suspension was added to an equal volume of molten $6 \%$ (wt/vol) agarose type VII in Earle Balanced Salt Solutions (EBSS) to yield a final cell concentration of $4 \times 10^{6}$ cells $/ \mathrm{ml}$ in $3 \%$ (wt/ vol) agarose (Sigma-Aldrich, Poole, UK). The 
chondrocyte/agarose suspension was transferred into a sterile stainless steel mold, containing holes $5 \mathrm{~mm}$ in diameter and $5 \mathrm{~mm}$ in height and allowed to gel at $4{ }^{\circ} \mathrm{C}$ for 20 minutes. Constructs were cultured in a defined culture medium comprising DMEM, 0.1 $\mu M$ dexamethasone, $0.17 \mathrm{~m} M$ ascorbate, $1 \mathrm{~m} M$ sodium pyruvate, 0.35 $\mathrm{m} M$ proline, $5 \mu \mathrm{g} / \mathrm{ml}$ penicillin, $5 \mu \mathrm{g} / \mathrm{ml}$ streptomycin, $20 \mathrm{~m} M$ Hepes buffer, $2 \mu M$ L-glutamine, ITS, and supplements $(6.25 \mu \mathrm{g} / \mathrm{ml}$ insulin, $6.25 \mu \mathrm{g} / \mathrm{ml}$ transferrin, $6.25 \mu \mathrm{g} / \mathrm{ml}$ seleneous acid, $5.33 \mu \mathrm{g} / \mathrm{ml}$ linoleic acid, and $1.25 \mu \mathrm{g} / \mathrm{ml}$ bovine serum albumin) at $37^{\circ} \mathrm{C}$ in $5 \% \mathrm{CO}_{2}$ for 24 hours (all from Cambrex Bioscience, Wokingham, UK).

\section{Dose-response effect of CNP in chondrocyte/agarose constructs}

The dose-response effect of CNP was examined in constructs cultured under free-swelling conditions to determine the appropriate concentration for mechanical loading studies. Constructs were cultured in $1 \mathrm{ml}$ of defined media supplemented with either low $(0,0.1,1$, $10,100 \mathrm{p} M)$ or high $(0,1,10,100,1000 \mathrm{n} M)$ concentrations of CNP in the presence and absence of $10 \mathrm{ng} / \mathrm{ml}$ IL-1 $\beta$ and/or $5 \mu M$ KT5823 for 48 hours (all from Sigma-Aldrich). KT5823 inhibits PKGII by competing directly with ATP at the catalytic domain. In each case, the medium was additionally supplemented with $1 \mu \mathrm{Ci}$ / $\mathrm{ml}\left[{ }^{3} \mathrm{H}\right]$-thymidine and $10 \mu \mathrm{Ci} / \mathrm{ml}^{35} \mathrm{SO}_{4}$ (both Amersham Biosciences Ltd, Bucks, UK) for the assessment of cell proliferation and proteoglycan synthesis, respectively. At the end of the culture period, the constructs and corresponding media were immediately stored at $-20^{\circ} \mathrm{C}$ before biochemical analysis.

\section{Application of dynamic compression}

In separate experiments, a fully characterized bioreactor compression system (Zwick Testing Machines, Leominster, UK) was used to determine the effect of CNP and dynamic loading on cell metabolism and gene expression in chondroycte/agarose constructs. The bioreactor has been extensively described previously [34-36]. To review briefly, equilibrated constructs were transferred into individual wells of a 24-well culture plate (Costar, High Wycombe, UK) and mounted within the bioreactor. One milliliter of defined media supplemented with 0 or $10 \mathrm{ng} / \mathrm{ml} \mathrm{IL-1} \beta$ in the presence and absence of low $(100 \mathrm{p} M)$ or high $(100 \mathrm{n} M)$ concentrations of CNP and/ or $5 \mu M$ KT5823 were introduced into each well. Strained constructs were subjected to dynamic compression ranging from 0 to $15 \%$ strain in a sinusoidal waveform at a frequency of $1 \mathrm{~Hz}$. The compression regimen was applied in an intermittent manner, with a profile of 1.5 hour compression followed by a 4.5 hour unstrained period for both the 6 and 48 hour culture periods. This resulted in duty cycles equivalent to 5400 and 43200, respectively. Control constructs were maintained in an unstrained state within the bioreactor system and cultured for the same time period. At the end of the culture period, the constructs and corresponding media were immediately stored at $-70^{\circ} \mathrm{C}$ before analysis.

\section{RNA isolation, CDNA synthesis, and real-time qPCR}

RNA was isolated from chondrocytes cultured in agarose by using protocols described in the QIAquick Spin gel extraction and RNeasy kits, as previously described (Qiagen, West Sussex, UK) [28,37]. By following manufacturer's instructions, Ambion's DNA-free DNase treatment and removal reagents were used to eliminate any contaminating DNA from the RNA sample (Ambion Applied Biosystems, Warrington, UK). RNA was quantified on the Nanodrop ND-1000 spectrophotometer (LabTech, East Sussex, UK), and reverse transcription was performed by using manufacturer's protocols from the Enhanced Avian RT First Strand cDNA synthesis kit, oligo $(\mathrm{dT})_{23}$ primer, and a total of $200 \mathrm{ng}$ of RNA (Sigma Genosys, Cambridge, UK). Real-time quantitative PCR assays coupled with LNA probes were performed in $25-\mu \mathrm{l}$ reaction mixtures containing $1 \mu \mathrm{l} \mathrm{cDNA}, 12.5$ $\mu \mathrm{l}$ JumpStart Taq PCR Master Mix, primer pairs, and probes detailed in Table 1 and nuclease-free PCR-grade water to $25 \mu \mathrm{l}$ (Sigma Genosys, Cambridge, UK). Each sample was run in duplicate on the 96-well thermal system of the Mx3000P quantitative PCR instrument (Stratagene, Amsterdam, The Netherlands). Thermocycling conditions comprised an initial polymerase activation step at $95^{\circ} \mathrm{C}$ for 3 minutes, followed by denaturation of 35 cycles at $95^{\circ} \mathrm{C}$ for 30 seconds, annealing at $55^{\circ} \mathrm{C}$ for 1 minute, and extension at $72^{\circ} \mathrm{C}$ for 1 minute. PCR efficiencies for optimal primer pair and probe concentrations were derived from standard curves $(n=3)$ by preparing a 10 -fold serial dilution of cDNA from a sample that represented the untreated control at time-zero conditions. The real-time PCR efficiencies (E) of amplification for each target was defined according to the relation, $\mathrm{E}=10^{[-1 / \text { slope }]}$. The $R^{2}$ value of the standard curve exceeded 0.9998 and revealed efficiency values presented in Table 1.

Fluorescence data were collected during the annealing stage of amplification, and data were analyzed on the MxPro qPCR software (version 3, Stratagene). Baselines and thresholds were automatically set by the RG-3000 qPCR software and used after manual inspection. The cycle threshold $\left(C_{t}\right)$ value for each duplicate reaction was expressed as the mean value, and the results were exported into Microsoft Excel for further analysis. The data obtained by PCR assay for GAPDH were validated as a reference gene by displaying the $C_{t}$ values as boxand-whisker plots, and the distribution examined under 
Table 1 Description of the LNA probe and primer sequences used to quantify gene expression

\begin{tabular}{|c|c|c|c|c|}
\hline Gene & Gene ID & Sequences & Product length & Efficiency \\
\hline iNOS & 4843 & $\begin{array}{l}\text { Probe: 5'-FAM-ACTTCTTTCCCGTCTCC-BHQ1-3' } \\
\text { Sense: 5'-TCCAGATAAGTGACATAAGTG-3' } \\
\text { Antisense: 5'-CAGCTTGACCAGAGATTC-3' }\end{array}$ & 305 & $\begin{array}{l}1.99 \\
\pm 0.8\end{array}$ \\
\hline $\operatorname{cox}-2$ & 5743 & $\begin{array}{l}\text { Probe: 5'-AAACTGCTCAACACCG-BHQ1-3' } \\
\text { Sense: 5'- GGACAGGATTCTATGGAG-3' } \\
\text { Antisense: 5'- GGATGTCAACACATAACTC-3' }\end{array}$ & 216 & $\begin{array}{l}1.99 \\
\pm 2.8\end{array}$ \\
\hline Aggrecan & 176 & $\begin{array}{l}\text { Probe: 5-'FAM-CCAACTCTTCAAGGTGA-BHQ1-3' } \\
\text { Sense: 5'-GACTGAAGTTCTTGGAGAA-3' } \\
\text { Antisense: 5'-CACGAAAACCCAGAGTAA-3' }\end{array}$ & 109 & $\begin{array}{l}1.98 \\
\pm 0.4\end{array}$ \\
\hline Collagen type II & 1280 & $\begin{array}{l}\text { Probe: 5'-FAM-TCTGTCTCCTTGCTTGCCA-BHQ1-3' } \\
\text { Sense: 5'-GGAGTCAAGGGTGATCGT-3' } \\
\text { Antisense: 5'-CTTGTGCACCAGCTTCTC-3' }\end{array}$ & 200 & $\begin{array}{l}1.99 \\
\pm 0.9\end{array}$ \\
\hline GAPDH & 2597 & $\begin{array}{l}\text { Probe: 5'-HEX-CAGTCAGCCGCATCTTCT-BHQ1-3' } \\
\text { Sense: 5'-TCTCTGCTCCTCCTGTTC-3' } \\
\text { Antisense: 5'-CGCCCAATACGACCAAAT-3' }\end{array}$ & 160 & $\begin{array}{l}1.98 \\
\pm 4.3\end{array}$ \\
\hline
\end{tabular}

Primers used in PCR experiments with Locked Nucleic Acid (LNA) probes produced amplicons between 109 and 305 base pairs and efficiency values between 1.98 and 1.99. Probes contain fluorescein (FAM) or 6-carboxyhexafluorescein (HEX) as the 5'-reporter dye and Black Hole Quencher 1 (BHQ1) as the 3'-quencher. Nucleotides highlighted in bold denote the LNA base.

mechanical loading conditions (data not shown). The $C_{t}$ values for GAPDH remained stable, with no changes detected under all culture conditions, suggesting its suitability as a reference gene. Relative quantification of iNOS, COX-2, aggrecan, and collagen type II signals were accomplished by normalizing each target to the reference gene, GAPDH, and to the calibrator sample by a comparative $C_{t}$ approach. For each sample, the ratio of target $\Delta \mathrm{Ct}$ and reference $\Delta \mathrm{Ct}$ was calculated, as previously described $[28,37]$.

\section{Biochemical analysis}

The production of NO was determined in media by converting nitrate to nitrite by using $1 \mathrm{unit} / \mathrm{ml}$ nitrate reductase in $40 \mu M$ NAPDH, $500 \mu M$ glucose 6-phosphate, $160 \mathrm{unit} / \mathrm{ml}$ glucose 6 -phosphate dehydrogenase and $20 \mathrm{~m} M$ Tris-HCL for 15 minutes at $37^{\circ} \mathrm{C}$. Total nitrite was assayed spectrophotometrically at $540 \mathrm{~nm}$ by using the Griess reaction. $\mathrm{PGE}_{2}$ production was measured in the culture media by using a high-sensitivity enzyme immunoassay according to manufacturer's instructions (Amersham Biosciences Ltd, Bucks, UK). $\left[{ }^{3} \mathrm{H}\right]$-thymidine incorporation was measured in constructs digested overnight at $37^{\circ} \mathrm{C}$ with $10 \mathrm{U} / \mathrm{ml}$ agarase followed by 1 hour at $60^{\circ} \mathrm{C}$ with $2.8 \mathrm{U} / \mathrm{ml}$ papain (both Sigma Chemical Co., Poole, UK) and analyzed with $10 \%$ trichloroacetic acid precipitation onto filters by using a Millipore Multiscreen system (Millipore, Watford, UK), as previously described $[29,34,35]$. Incorporation of
${ }^{35} \mathrm{SO}_{4}$ was determined in both agarase/papain digests and the culture media by using the Alcian blue precipitation method, as previously described $[29,34,35]$. Total DNA content remained stable throughout the culture conditions was assayed by using the Hoescht dye 33258 in agarose/papain digests.

\section{Statistics}

For dose-response studies, data represent the mean and SEM values of six replicates from three separate experiments. For the mechanical loading experiments, biochemical and gene-expression data represent the mean and SEM values of eight replicates from three separate experiments. Statistical analysis was performed with a two-way analysis of variance (ANOVA) and the multiple post hoc Bonferroni-corrected $t$ tests to compare differences between the various treatment groups, as indicated in the figure legend. For gene-expression data, ratio values were log transformed before analysis by a two-way ANOVA and the post hoc Bonferroni-corrected $t$ test. In all cases, a level of $5 \%$ was considered statistically significant $(P<0.05)$.

\section{Results CNP differentially regulates cell metabolism in a dose- dependent manner}

Chondrocytes cultured in agarose constructs produce significant amounts of $\mathrm{NO}$ and $\mathrm{PGE}_{2}$ release in response to IL-1 $\beta$ (both $P$ values $<0.001$; Figure $1 \mathrm{a}$ and $1 \mathrm{~b}$, 

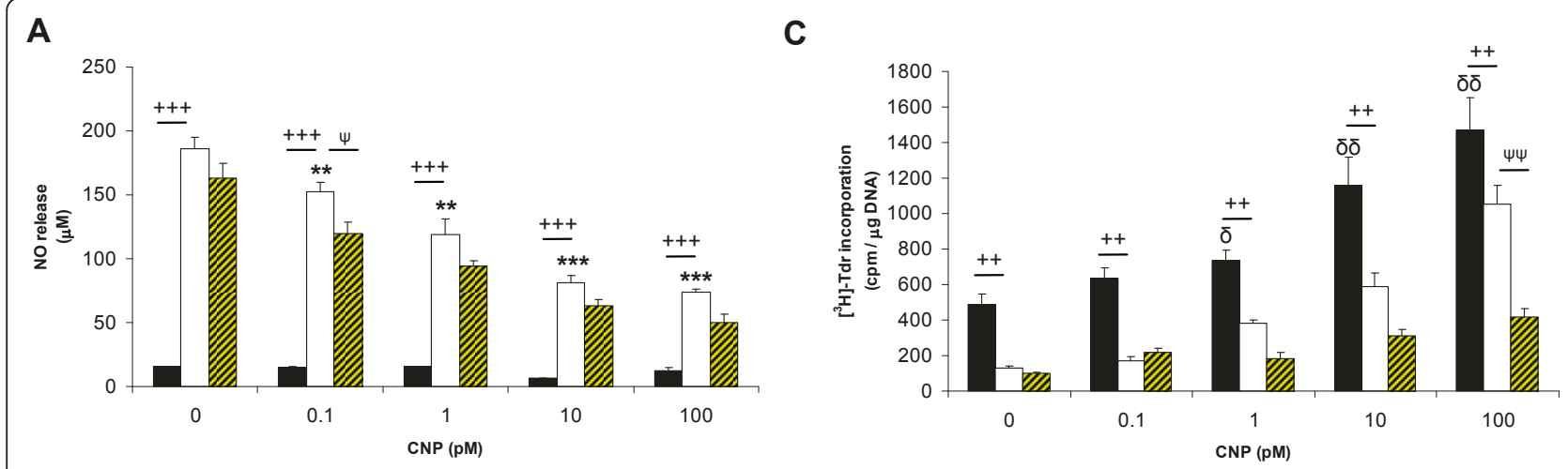

B

D
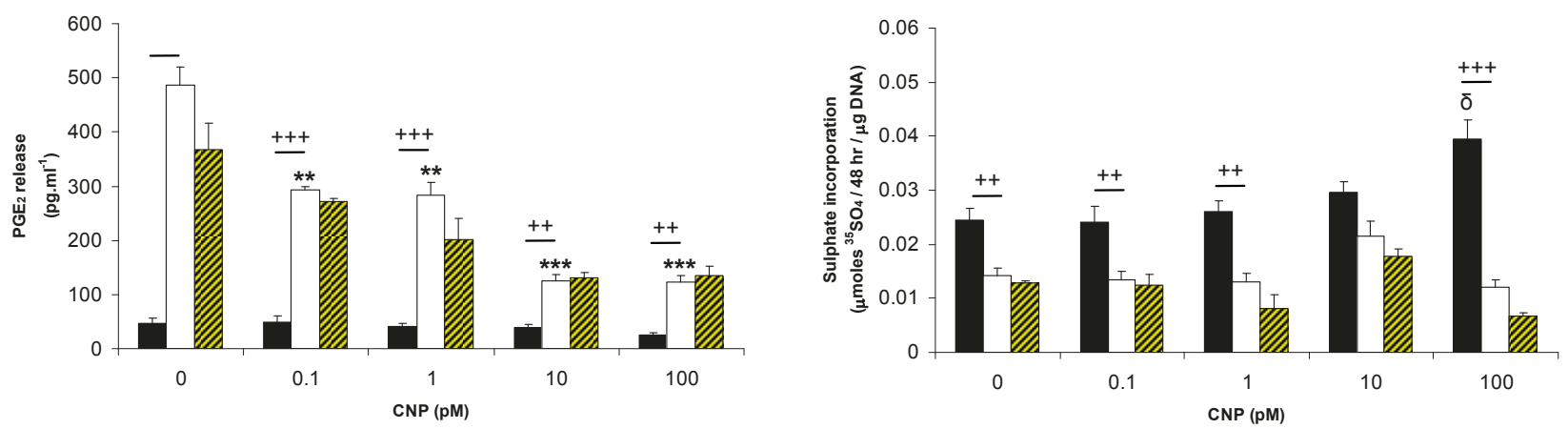

CNP

$\mathrm{CNP}+\geqslant \underset{\mathrm{IL}-1 \beta}{\mathrm{CNP}+\mathrm{IL}-1 \beta+}$
$\mathrm{KT} 5823$

Figure 1 Dose-response effect of low concentrations of CNP. Chondrocyte/agarose constructs were cultured under free-swelling conditions

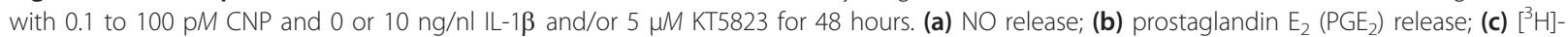
thymidine; and $(\mathbf{d}){ }^{35} \mathrm{SO}_{4}$ incorporation $(n=6)$. $(\delta)$, significant comparisons for untreated versus CNP; $(*)$, significant comparisons for $\mathrm{IL}-1 \beta$ versus

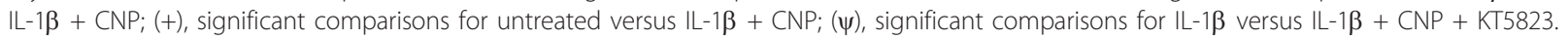

respectively). To examine whether $\mathrm{CNP}$ and the selective PKGII inhibitor could influence the IL-1 $\beta$-induced $\mathrm{NO}$ and $\mathrm{PGE}_{2}$ release, constructs were cultured with IL$1 \beta$ and CNP at concentrations ranging from 0.1 to 100 $\mathrm{p} M$ in the presence and absence of KT5823. It was evident that CNP reduced IL- $1 \beta$ induced $\mathrm{NO}$ and $\mathrm{PGE}_{2}$ release in a dose-dependent manner, with maximal inhibition at 10 and $100 \mathrm{p} M$ when compared with IL-1 $\beta$ treated constructs (all $P<0.001$ ). Treatment with IL-1 $\beta$ and the PKGII inhibitor did not influence $\mathrm{NO}$ and $\mathrm{PGE}_{2}$ levels in constructs cultured with CNP (Figures 1a and 1b). In the absence of IL- $1 \beta$, CNP increased $\left[{ }^{3} \mathrm{H}\right]$-thymidine incorporation in a dose-dependent manner $(P<$ 0.01; Figure 1c), whereas this effect of CNP was reduced by IL-1 $\beta$ and/or KT5823 $(P<0.01)$. At $100 \mathrm{p} M$, CNP increased ${ }^{35} \mathrm{SO}_{4}$ incorporation $(P<0.05$; Figure $1 \mathrm{~d})$, and this effect was reduced by IL- $1 \beta(P<0.001)$ and not further influenced with KT5823.

Figure 2 presents the dose-response effects of CNP at concentrations ranging from 0.1 to $1000 \mathrm{n} M$ in constructs cultured with IL-1 $\beta$ and/or KT5823 (Figure 2). IL-1 $\beta$-induced $\mathrm{NO}$ and $\mathrm{PGE}_{2}$ release was reduced by CNP in a dose-dependent manner (Figure 2a). However, the effect was most pronounced in the presence of $1 \mathrm{n} M \mathrm{CNP}$, which completely abolished the IL-1 $\beta$-induced $\mathrm{PGE}_{2}$ release $(P<0.001$; Figure $2 \mathrm{~b})$. Treatment with CNP and the PKGII inhibitor had no further effect on the reduction of IL-1 $\beta$-induced release of both $\mathrm{NO}$ and $\mathrm{PGE}_{2}$. At $1 \mathrm{n} M$, CNP increased $\left[{ }^{3} \mathrm{H}\right]$-thymidine incorporation when compared with untreated controls $(P<0.05$; Figure $2 \mathrm{c})$. The presence of IL-1 $\beta$ inhibited $\left[{ }^{3} \mathrm{H}\right]$-thymidine incorporation and the response was not significantly influenced by CNP and/or the PKGII inhibitor (Figure 2c). In contrast, $\mathrm{CNP}$ increased ${ }^{35} \mathrm{SO}_{4}$ incorporation in a dose-dependent manner with maximal stimulation at 100 and $1000 \mathrm{n} M(P<0.001$; Figure $2 \mathrm{~d})$. The presence of IL-1 $\beta$ inhibited ${ }^{35} \mathrm{SO}_{4}$ incorporation, and the levels were enhanced with CNP at 100 and $1000 \mathrm{n} M$, only. However, stimulation of ${ }^{35} \mathrm{SO}_{4}$ incorporation by CNP 

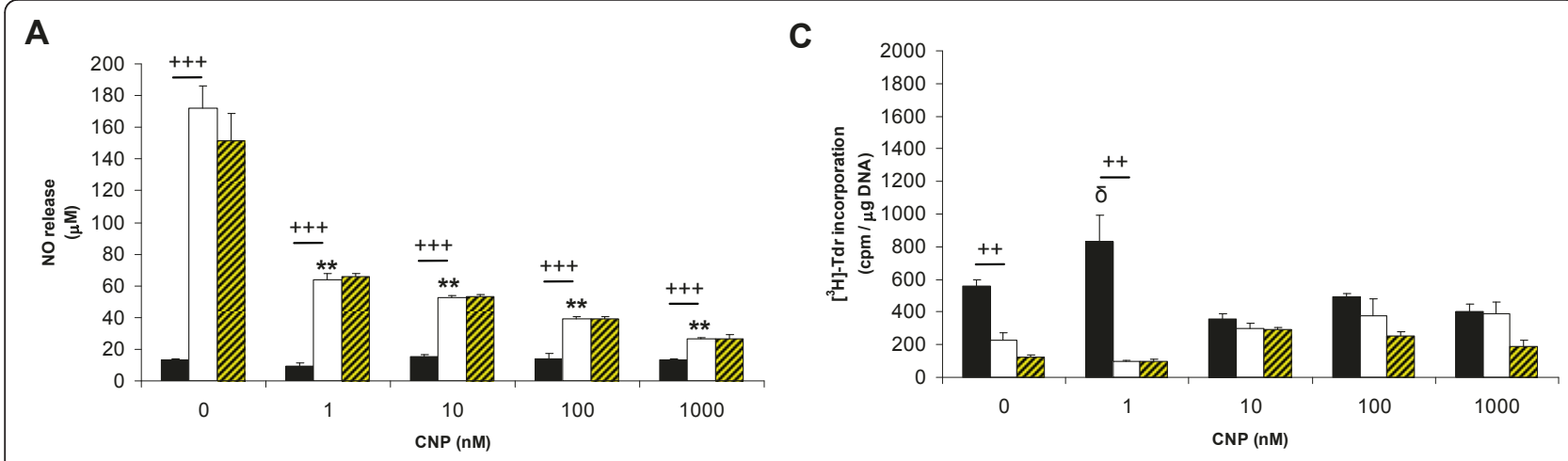

B

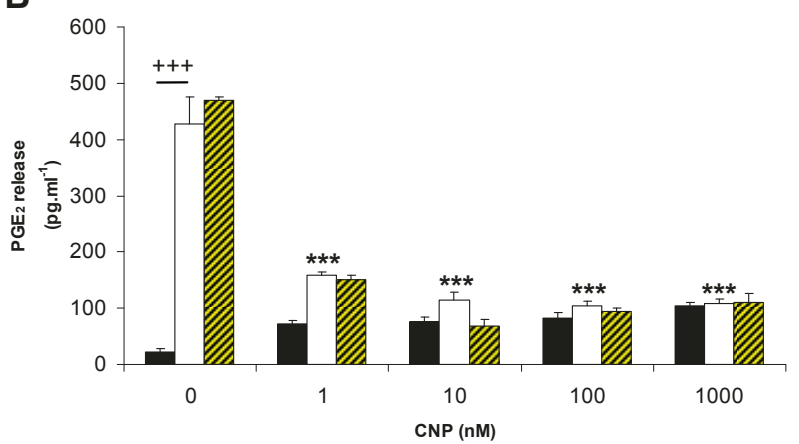

D

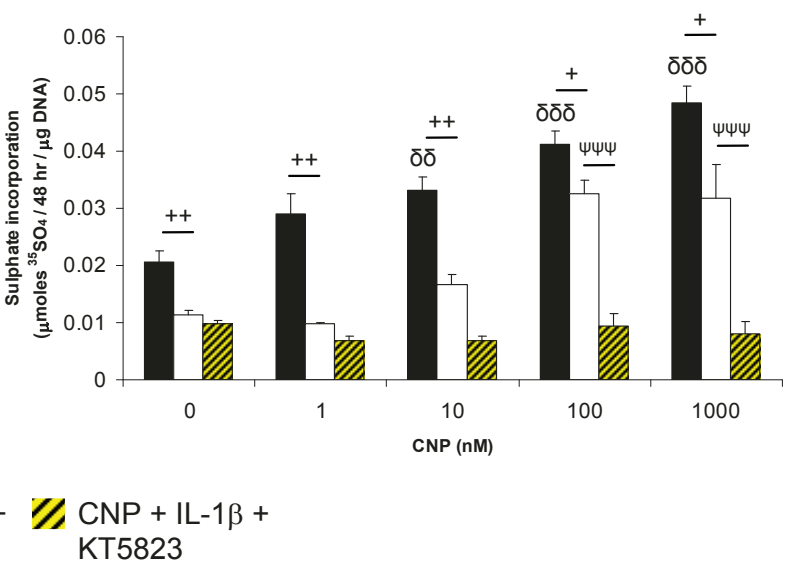

Figure 2 Dose-response effect of high concentrations of CNP. Chondrocyte/agarose constructs were cultured under free-swelling conditions with 1 to $1000 \mathrm{nM} C N P$ and 0 or $10 \mathrm{ng} / \mathrm{nl} \mathrm{IL-1 \beta}$, and/or $5 \mu M$ KT5823 for 48 hours. (a) NO release; (b) prostaglandin $E_{2}\left(P_{G E}\right)$ release; (c) [3 H]thymidine; and $(\mathbf{d}){ }^{35} \mathrm{SO}_{4}$ incorporation $(n=6)$. $(\delta)$, significant comparisons for untreated versus CNP; $(*)$, significant comparisons for IL- $1 \beta$ versus IL-1 $\beta+$ CNP; $(+)$, significant comparisons for untreated versus IL-1 $\beta+$ CNP; $(\psi)$, significant comparisons for IL-1 $\beta$ versus IL-1 $\beta+$ CNP + KT5823.

in IL-1 $1 \beta$-treated constructs was abolished in the presence of the PKGII inhibitor $(P<0.001$; Figure $2 \mathrm{~d})$.

CNP and dynamic compression counteract IL-1 $\beta$-induced $\mathrm{NO}$ and $\mathrm{PGE}_{2}$ release and restore cell proliferation and proteoglycan synthesis

In separate experiments, the effects of CNP and dynamic compression were examined in constructs cultured with IL-1 $\beta$ and/or the PKGII inhibitor by using either low $(100 \mathrm{p} M)$ or high $(100 \mathrm{n} M)$ concentrations of the peptide (Figure 3). In the absence and presence of CNP, dynamic compression reduced NO release $(P<$ 0.001; Figure 3a) but had no significant effect on $\mathrm{PGE}_{2}$ levels (Figure $3 \mathrm{~b}$ ). In unstrained constructs, the presence of IL- $1 \beta$ increased $\mathrm{NO}$ and $\mathrm{PGE}_{2}$ release, and the response was reduced by dynamic compression, CNP, and/or both stimuli (all $P<0.001$ ). Stimulation with $\mathrm{CNP}$ and/or dynamic compression in the presence of the PKGII inhibitor further reduced $\mathrm{NO}$ and $\mathrm{PGE}_{2}$ release in IL- $1 \beta$-treated constructs (both $P<0.01$; Figure $3 \mathrm{a}$ and $3 \mathrm{~b}$, respectively). In contrast, dynamic compression increased $\left[{ }^{3} \mathrm{H}\right]$-thymidine incorporation in the presence and absence of CNP $(P<0.001$; Figure $3 \mathrm{c})$. This effect was inhibited with IL-1 $\beta$ and could be reversed by stimulation with $100 \mathrm{p} M$ CNP, dynamic compression, or both. The presence of the PKGII inhibitor blocked CNP-induced stimulation of $\left[{ }^{3} \mathrm{H}\right]$-thymidine incorporation in IL- $1 \beta$-treated constructs. The opposite effect was found for ${ }^{35} \mathrm{SO}_{4}$ incorporation, whereby stimulation with $100 \mathrm{n} M \mathrm{CNP}$ and dynamic compression induced the greatest response when compared with untreated controls or constructs cultured with $100 \mathrm{n} M$ CNP $(P<0.001$; Figure $3 d)$. The IL-1 $\beta$-induced inhibition of ${ }^{35} \mathrm{SO}_{4}$ incorporation was reversed by both 100 $\mathrm{n} M \mathrm{CNP}$ and dynamic compression $(P<0.001)$ and inhibited with KT5823 (Figure 3d).

\section{CNP and dynamic compression modulate IL-1 $\beta$-induced gene expression}

To investigate the effect of CNP on the expression of catabolic and anabolic genes, constructs were subjected to dynamic compression over 6 and 48 hour period in 


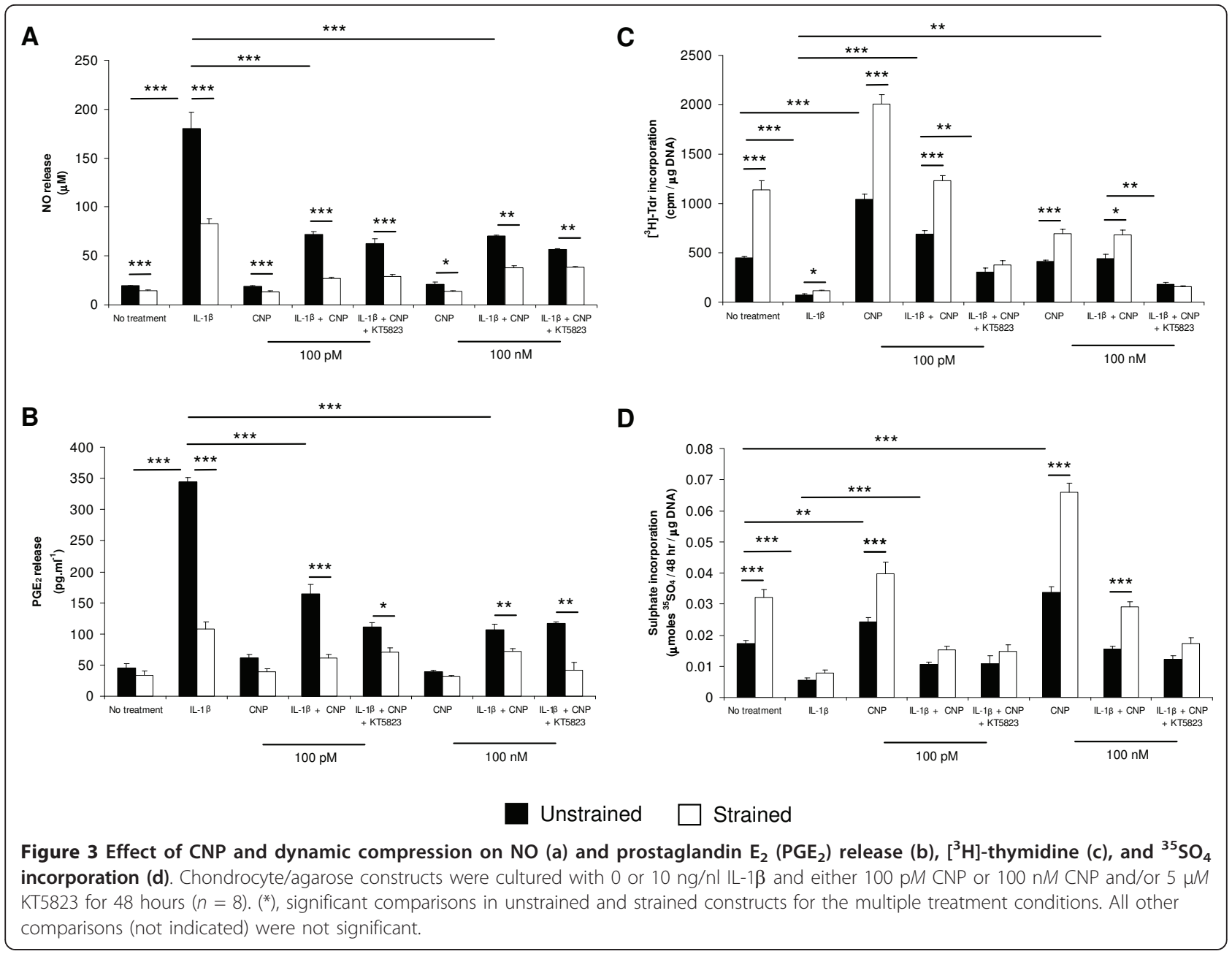

the presence and absence of low (100 pM) and high (100 $\mathrm{n} M)$ concentrations of the peptide (Figure 4). In unstrained constructs, IL- $1 \beta$ induced iNOS and COX-2 expression at 6 and 48 hours (all $P<0.001$; Figure 4 a and $4 \mathrm{~b}$, respectively). At 6 and 48 hours, the IL-1 $\beta$ induced iNOS and COX-2 expression was inhibited by dynamic compression (both $P<0.001$ ) or by the presence of low (both $P<0.01$ ) or high concentrations of CNP (both $P<0.01$ ). A combination of dynamic compression and CNP reduced iNOS and COX expression at 6 hours, with levels returning to basal values with IL$1 \beta$ at 48 hours. This effect was not significantly influenced further with KT5823 in constructs cultured with IL- $1 \beta$ and CNP. In contrast, dynamic compression increased aggrecan and collagen type II expression at 6 hours but not at 48 hours (both $P<0.05$; Figure $4 \mathrm{c}$ and $4 \mathrm{~d}$, respectively). In unstrained constructs, stimulation with CNP increased aggrecan and collagen type II expression in a concentration-dependent manner and the effect was further enhanced with dynamic compression at either 6 or 48 hours. In unstrained constructs,
IL-1 $\beta$ inhibited aggrecan and collagen type II expression and the effect was reversed with dynamic compression $(P<0.001), 100 \mathrm{n} M \mathrm{CNP}(P<0.05)$, or both at $6(P<$ $0.01)$ and 48 hours $(P<0.05)$ for aggrecan expression. In contrast, stimulation by $100 \mathrm{p} M$ or $100 \mathrm{n} M C N P$ and dynamic compression reversed the IL-1 $\beta$-induced inhibition of collagen type II expression at 6 (both $P<0.01$ ) and 48 hours (both $P<0.05$; Figure $4 \mathrm{~d}$ ). The compression-induced stimulation of aggrecan and collagen type II expression was inhibited with KT5823 in constructs cultured with IL-1 $\beta$ and CNP.

\section{Discussion}

CNP is expressed in the growth plate and regulates endochondral ossification through increased cell proliferation and hypertrophy and stimulates production of cartilage matrix proteins $[13,14,19,38,39]$. The molecular mechanisms that control these processes are not completely understood. In addition, it is unclear whether the effects of CNP in adult cartilage are influenced by mechanical signals that modulate matrix synthetic 


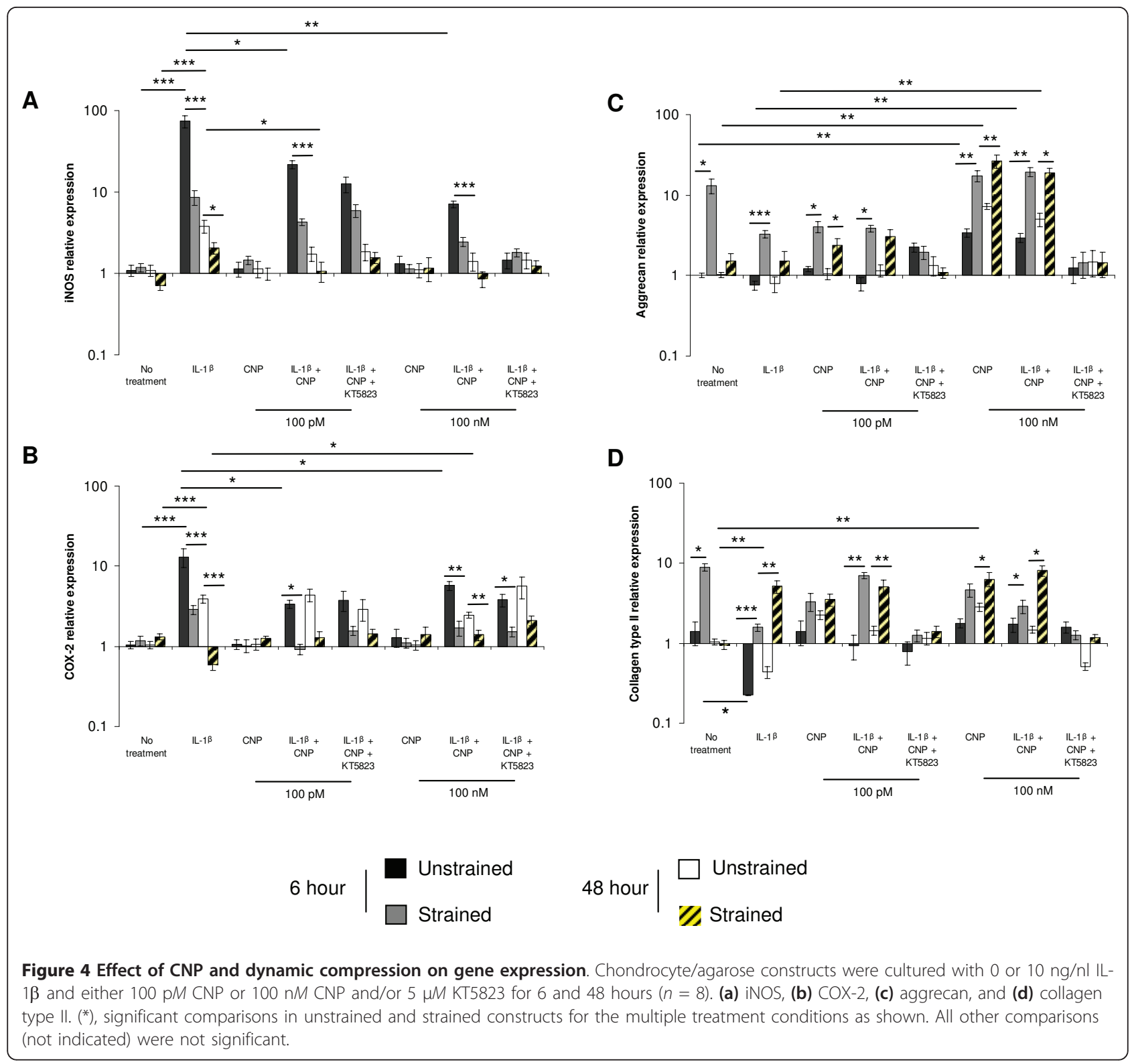

activity and inflammatory pathways. However, the response to mechanical signals, in part, is dependent on the type of mechanical loading regime, its duration, and whether loading was applied during the early or late stage of the disease process. Consequently, stimulation of chondrocytes with natriuretic peptides and mechanical signals may potentially serve to modulate cell proliferation and increase matrix synthesis in the OA joint. The present study therefore examined the effect of CNP and mechanical signals in an in vitro inflammatory chondrocyte/agarose model.

Initial studies examined the dose-response effect of CNP on cell proliferation and proteoglycan synthesis and whether the peptide could stimulate anabolic activities by blocking the catabolic mediators induced by IL-1 $\beta$. In the absence of the cytokine, low concentrations of CNP (10 to $100 \mathrm{pM}$ ) increased cell proliferation without affecting proteoglycan synthesis in chondrocyte/ agarose constructs. The opposite effect was found for high concentrations of CNP (100 to $1000 \mathrm{n} M$ ), which increased proteoglycan synthesis without any significant change in cell proliferation. Our data are in agreement with previous studies that demonstrate differential effects of CNP in chondrocytes cultured in monolayer $[13,14]$. Other studies have shown that stimulation by CNP increased cell proliferation in growth-plate chondrocytes and chondrogenic cell lines and enhanced GAG synthesis and cell-adhesion molecules in 
mesenchymal cells [39-41]. In addition, CNP increased the expression of genes involved in proteoglycan synthesis and inhibited the expression of proteinase enzymes involved in matrix breakdown $[12,39,41]$. CNP therefore plays a significant role in regulating chondrocytes and contributes to the structural properties of cartilage tissue $[15,40,42]$. However, CNP has never been implicated in $\mathrm{OA}$ and the importance of this pathway in chondrocytes is not known. In the present study, biochemical analysis revealed that under IL- $1 \beta$ conditions, CNP inhibits $\mathrm{NO}$ and $\mathrm{PGE}_{2}$ production in a dose-dependent manner and restores cell proliferation and proteoglycan synthesis. The reparative effect involved PKGII-dependent mechanisms and was influenced by the concentration of CNP, resulting in greater levels of matrix synthesis with nanomolar concentrations in IL-1 $\beta$-treated constructs. In contrast, picomolar concentrations of CNP increased cell proliferation in the presence of IL$1 \beta$, and the response was blocked with the PKGII inhibitor. A recent study showed that CNP can induce hypertrophy in chondrocytes, which may contribute to OA disease progression $[43,44]$. In the present study, stimulation with CNP resulted in differential effects, such that low doses increased gene expression of type I collagen, type $\times$ collagen, and MMP-13 without affecting collagen type II mRNA (Table 2). In contrast, high concentrations had the opposite effect and increased type II collagen gene expression and inhibited type I collagen and MMP-13 in free-swelling constructs (Table 2). Whilst the CNP and PKGII pathways might be used in the treatment of growth retardation, concentration-dependent effects of CNP should be further addressed to ensure that their potential damaging effects of CNP are not evoked in cartilage.

Both CNP and NO stimulate the synthesis of cGMP and lead to activation of common downstream pathways, involving PKGII. In the present study, the PKGII inhibitor did not influence the levels of $\mathrm{NO}$ and $\mathrm{PGE}_{2}$ release following CNP and/or IL-1 $\beta$ treatment, implicating alternative mechanisms. For example, the cGMP pathways are likely to cross-talk with the catabolic pathways because of elevated levels of NO induced by IL- $1 \beta$. More specifically, NO binds to the heme-containing soluble protein, guanylyl cyclase (sGC), and stimulates cGMP levels, which contribute to the production of PKG and cGMP-regulated phosphodiesterase (PDE) subtypes [45]. NO will change the function of other hemecontaining proteins, such as COX-2 and increase $\mathrm{PGE}_{2}$ production. In a previous study, overstimulation of the PKGI pathway was shown to block IGF-1-induced proteoglycan synthesis in chondrocyte monolayers [46]. Indeed, it was previously reported with human chondrocytes that enhanced cGMP levels lead to alterations in the PDE5 subtype and matrix breakdown. This effect was mediated by the induction of iNOS and NO release with IL-1 $\beta$ [47]. This is in contrast to chemical inhibitor studies for PDE4, which showed a partial inhibition of NO release in OA chondrocytes [48]. Thus, pharmacologic inhibitors selective for PDE subtypes may reduce the catabolic response in chondrocytes. Some evidence indicates a functional role of PDE4 in downregulating the IGF-1-binding proteins, which are known to contribute to OA pathogenesis [49-51]. The action of elevated cytokine-induced NO/cGMP pathways and complex interplay with CNP is unknown and requires further investigation.

It is well established that $\mathrm{NO}$ and $\mathrm{PGE}_{2}$ accelerate chondrocyte-mediated matrix degradation, inflammation, and apoptosis $[1,52]$. NO is also an important signaling molecule in cartilage in response to different stimuli, including pro-inflammatory cytokines and mechanical signals $[7,26,28]$. We therefore examined whether mechanical signals could influence NO and $\mathrm{PGE}_{2}$ levels in chondrocyte/agarose constructs cultured with IL-1 $\beta$ and either low $(100 \mathrm{p} M)$ or high $(100 \mathrm{n} M)$ concentrations of CNP. In the presence and absence of IL-1 $\beta$, stimulation with mechanical signals and CNP induced the expression of aggrecan and collagen type II and increased cell proliferation and proteoglycan synthesis in a concentration-dependent manner. The anabolic

Table 2 Effect of CNP on gene expression in chondrocyte/agarose constructs

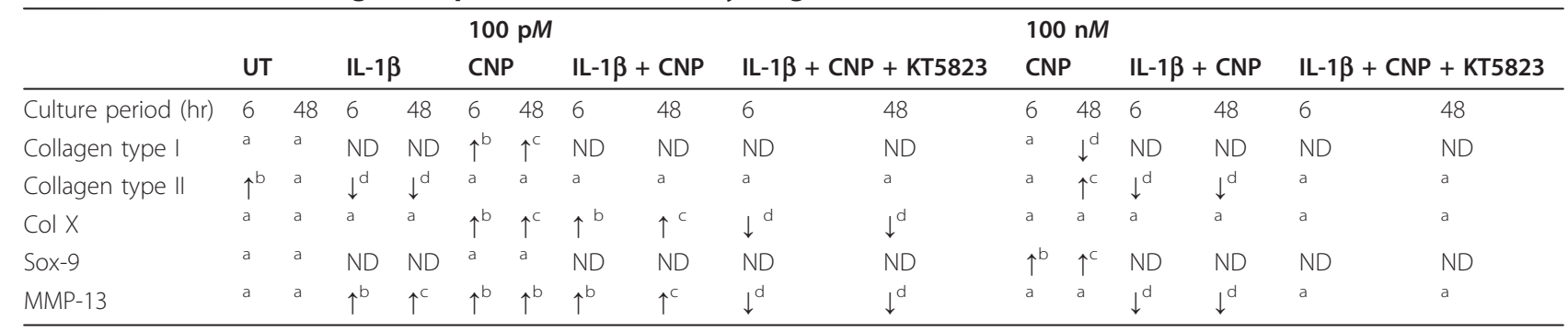

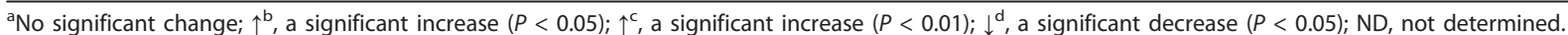
Chondrocyte/agarose constructs were cultured with low (100 pM) or high (100 nM) concentrations of CNP with 0 or $10 \mathrm{ng} / \mathrm{ml}$ IL-1 $\beta$ and/or $5 \mu M$ KT5823 for 6 and 48 hours $(n=8)$. Note that statistical comparisons were determined for the following samples: Time $=0$ versus 6 or 48 hr (UT); UT versus IL-1 $\beta$; UT versus CNP; IL-1 $\beta$ versus IL-1 $\beta+$ CNP; IL-1 $\beta+$ CNP versus IL-1 $\beta+$ CNP + KT5823. 
response was blocked by the PKGII inhibitor. It is plausible that PKGII represents the principal mediators of cGMP signals and therefore has a positive role in cartilage homeostasis. In the presence of IL-1 $\beta$, both mechanical signals and CNP reduced iNOS and COX-2 expression and $\mathrm{NO}$ and $\mathrm{PGE}_{2}$ production. This is the first study to show that CNP and mechanical signals block catabolic activities and rescue anabolic events in chondrocyte/agarose constructs cultured with IL-1 $\beta$. These findings open the possibility of using CNP in the treatment of damaged cartilage in conjunction with controlled levels of mechanical loading. Some evidence in chondrocytes suggests that physiological mechanical signals stimulate production and secretion of growth factors, substance $\mathrm{P}$, and IL-4 that mediate extracellular matrix synthesis and remodelling [3]. CNP additionally mediates matrix response through regulation of cGMP regulated ion channels (CGi) [51]. These cyclic nucleotide-gated channels belong to the superfamily of voltage-gated ion channels that regulate membrane potentials and could evoke calcium $\left(\mathrm{Ca}^{2+}\right)$ entry in chondrocytes $[53,54]$. We previously showed that the stretch-activated (SA) ion channels and the integrins mediate mechanical loading induced calcium signaling and regulate anabolic and catabolic pathways in chondrocytes $[3,28,55,56]$. The contrasting effects are due in part to different temporal dynamics and magnitude of the kinases and transcription factors, which are influenced by the cytokines or mechanical loading. Thus, further studies should examine the molecular pathways induced by CNP and mechanical signals in inflammatory chondrocytes. The proposed interactions of CNP with mechanical signals are illustrated in Figure 5.

In summary, CNP treatment leads to significant increases in anabolic activities and the reduction of catabolic mediators in the presence of IL-1 $\beta$. The anabolic response was PKGII mediated and could be enhanced by mechanical signals in a synergistic manner. The catabolic response was not influenced by the PKGII inhibitor, implicating alternative mechanisms involving the

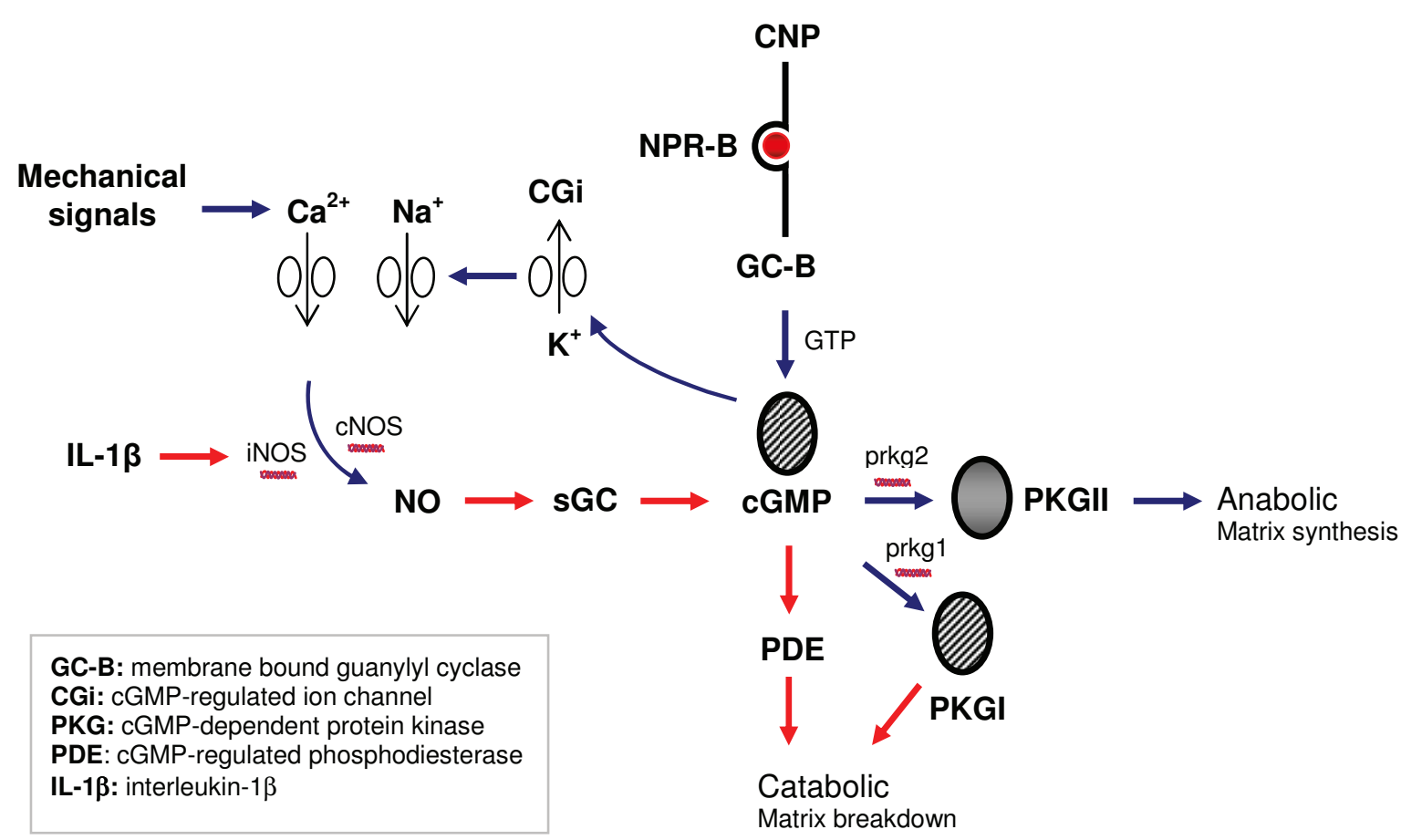

Figure 5 Proposed signaling interactions between CNP and mechanical signals in chondrocytes. C-type natriuretic peptide (CNP) binding to the natriuretic peptide receptor-B (NPR-B) activates the extracellular domain of guanylyl cyclase B (GC-B), leading to increased levels of 3,5'cyclic guanosine monophosphate (cGMP). The accumulation of cGMP levels modulates the downstream activities of cGMP-dependent protein kinases (PKGI and II), CGMP-regulated ion channels (CGi), and cGMP-regulated phosphodiesterase (PDE) subtypes. PKGII mediates matrix synthesis augmented by mechanical signals that influence CGi ion channels. However, the CGMP pathways are likely to crosstalk with the catabolic pathways because of elevated levels of nitric oxide (NO) induced by interleukin-1 $(\mathrm{IL}-1 \beta$ ). More specifically, NO binds to the heme-containing soluble protein, guanylyl cyclase (sGC), and stimulates cGMP levels, which contribute to the production of PKGl or PDE subtypes, leading to matrix breakdown. 
PDEs. Further studies will examine the relation between CNP and mechanical loading in detail, because these signals converge on a common mediator, cGMP. For instance, because NO is an established player in mediating both mechanical and inflammatory signals in cartilage, we will determine which components of the CNP and mechanical loading pathways interfere with the cytokine-induced NO pathway and whether these factors directly regulate each other or cross-talk with other signaling routes.

\section{Conclusions}

Therapeutic agents like CNP could be administered in conjunction with controlled exercise therapy to slow OA disease progression and maintain cartilage health. The findings from this research provide the potential for developing a novel agent to slow the pathophysiologic mechanisms and to treat OA in the young and old.

\section{Abbreviations}

CGMP: 3,5'-cyclic guanosine monophosphate; CNP: C-type natriuretic peptide GC-B: guanylyl cyclase B; IL-1ß: interleukin-1 $\beta$; NO: nitric oxide; PDE: CGMPregulated phosphodiesterase; $\mathrm{PGE}_{2}$ : prostaglandin $\mathrm{E}_{2}$; $\mathrm{PKGIl}$ : cyclic GMPdependent protein kinase II.

\section{Acknowledgements}

The work was supported by the AO Research Fund of the AO Foundation (S-09-83C) and Arthritis Research UK (19646 and 17026).

\section{Author details}

${ }^{1}$ School of Engineering and Materials Science, Queen Mary University of London, Mile End Road, London E1 4NS, UK. '2Department of Trauma and Orthopaedics, Barts and The London School of Medicine and Dentistry, Queen Mary University of London, Whitechapel Road, London E1 1BB, UK. ${ }^{3}$ Molecular Medicine Centre, Western General Hospital, University of Edinburgh, Crew Road, Edinburgh EH4 2XU, UK.

\section{Authors' contributions}

MR and TC carried out the experiments and analysis, participated in the experimental design, data analysis, and manuscript drafting. DL and DS participated in the experimental design, data analysis, and manuscript drafting. All authors read and approved the final manuscript.

\section{Competing interests}

The authors declare that they have no competing interests.

Received: 25 February 2011 Revised: 2 August 2011

Accepted: 13 September 2011 Published: 13 September 2011

\section{References}

1. Amin AR, Abramson SB: The role of nitric oxide in articular cartilage breakdown in osteoarthritis. Curr Opin Rheumatol 1998, 10:263-268.

2. Fitzgerald JB, Jin M, Grodzinsky AJ: Shear and compression differentially regulate clusters of functionally related temporal transcription patterns in cartilage tissue. J Biol Chem 2006, 281:24095-24103.

3. Millward-Sadler SJ, Salter DM: Integrin-dependent signal cascades in chondrocyte mechanotransduction. Ann Biomed Eng 2004, 32:435-446.

4. Malemud $\mathrm{CJ}$ : Protein kinases in chondrocyte signaling and osteoarthritis. Clin Orthop Relat Res 2004, (427 Suppl):S145-S151.

5. Griffin TM, Guilak F: The role of mechanical loading in the onset and progression of osteoarthritis. Exerc Sport Sci Rev 2005, 33:195-200.

6. Blom AB, van der Kraan PM, van den Berg WB: Cytokine targeting in osteoarthritis. Curr Drug Targets 2007, 8:283-292.
7. Guilak F, Fermor B, Keefe FJ, Kraus VB, Olson SA, Pisetsky DS, Setton LA, Weinberg JB: The role of biomechanics and inflammation in cartilage injury and repair. 2004, 423:17-26.

8. Loeser RF: Molecular mechanisms of cartilage destruction: mechanics, inflammatory mediators, and aging collide. Arthritis Rheum 2006, 54:1357-1360.

9. Chusho H, Tamura N, Ogawa Y, Yasoda A, Suda M, Miyazawa T, Nakamura K, Nakao K, Kurihara T, Komatsu Y, Itoh H, Tanaka K, Saito Y, Katsuki M, Nakao K: Dwarfism and early death in mice lacking C-type natriuretic peptide. Proc Natl Acad Sci USA 2001, 98:4016-4021.

10. Schulz S: C-type natriuretic peptide and guanylyl cyclase $B$ receptor. Peptides 2005, 26:1024-1034.

11. Kuhn M: Molecular physiology of natriuretic peptide signalling. Basic Res Cardiol 2004, 99:76-82.

12. Krejci $P$, Masri B, Fontaine $V$, Mekikian PB, Weis M, Prats $H$, Wilcox WR: Interaction of fibroblast growth factor and C-natriuretic peptide signaling in regulation of chondrocyte proliferation and extracellular matrix homeostasis. J Cell Sci 2005, 118:5089-5100.

13. Waldman SD, Usmani Y, Tse MY, Pang SC: Differential effects of natriuretic peptide stimulation on tissue engineered cartilage. Tissue Eng Part $A$ 2008, 14:441-448.

14. Agoston H, Baybayan L, Beier F: Dexamethasone stimulates expression of C-type natriuretic peptide in chondrocytes. BMC Musculoskel Disord 2006, 7:87.

15. Hagiwara H, Sakaguchi H, Itakura M, Yoshimoto T, Furuya M, Tanaka S, Hirose S: Autocrine regulation of rat chondrocyte proliferation by natriuretic peptide $C$ and its receptor, natriuretic peptide receptor-B. J Biol Chem 1994, 269:10729-10733.

16. Hagiwara H, Inoue A, Yamaguchi A, Yokose S, Furuya M, Tanaka S, Hirose S: cGMP produced in response to ANP and CNP regulates proliferation and differentiation of osteoblastic cells. Am J Physiol 1996, 270:C1311-C1308.

17. Pfeifer A, Ruth P, Dostmann W, Sausbier M, Klatt P, Hofmann F: Structure and function of cGMP-dependent protein kinases. Rev Physiol Biochem Pharmacol 1999, 135:105-149.

18. Komatsu Y, Chusho H, Tamura N, Yasoda A, Miyzawa T, Suda M, Miura M, Ogawa $Y$, Nako K: Significance of C-type natriuretic peptide (CNP) in endochondral ossification: analysis of CNP knockout mice. J Bone Miner Metab 2002, 20:331-336.

19. Yasoda A, Ogawa Y, Suda M, Tamura N, Mori K, Sakuma Y, Chusho H, Shiota K, Tanaka K, Nakao K: Natriuretic peptide regulation of endochondral ossification: evidence for possible roles of the C-type natriuretic peptide/guanylyl cyclase-B pathway. J Biol Chem 1998, 273:11695-11700.

20. Yasoda A, Komatsu Y, Chusho H, Miyazawa T, Ozasa A, Miura M, Kurihara T, Rogi T, Tanaka S, Suda M, Tamura N, Ogawa Y, Nakao K: Overexpression of CNP in chondrocytes rescues achondroplasia through an MAPKdependent pathway. Nat Med 2004, 10:80-86

21. Pelletier JP, DiBattista JA, Roughley P, McCollum R, Martel-Pelletier J: Cytokines and inflammation in cartilage degradation. Rheum Dis Clin North Am 1993, 19:545-568.

22. Saklatvala J: Tumour necrosis factor alpha stimulates resorption and inhibits synthesis of proteoglycan in cartilage. Nature 1986, 322:547-549.

23. Häuselmann HJ, Oppliger L, Michel BA, Stefanovic-Racic M, Evans CH: Nitric oxide and proteoglycan biosynthesis by human articular chondrocytes in alginate culture. FEBS Lett 1994, 352:361-364.

24. Shakibaei M, John T, Schulze-Tanzil G, Lehmann I, Mobasheri A: Suppression of NF-kappaB activation by curcumin leads to inhibition of expression of cyclo-oxygenase- 2 and matrix metalloproteinase-9 in human articular chondrocytes: implications for the treatment of osteoarthritis. Biochem Pharmacol 2007, 73:1434-1445.

25. Deschner J, Hofman CR, Piesco NP, Agarwal S: Signal transduction by mechanical strain in chondrocytes. Curr Opin Clin Nutr Metab Care 2003, 6:289-293.

26. Madhavan S, Anghelina M, Rath-Deschner B, Deschner J, Piesco N, Agarwal S: Biomechanical signals exert sustained attenuation of proinflammatory gene induction in articular chondrocytes. Osteoarthrit Cart 2006, 14:1023-1032.

27. De Croos JN, Dhaliwal SS, Grynpas MD, Pilliar RM, Kandel RA: Cyclic compressive mechanical stimulation induces sequential catabolic and anabolic gene changes in chondrocytes resulting in increased extracellular matrix accumulation. Matrix Biol 2006, 25:323-331. 
28. Chowdhury TT, Arghandawi S, Brand J, Akanji OO, Salter DM, Bader DL, Lee DA: Dynamic compression counteracts IL-1 $\beta$ induced inducible nitric oxide synthase and cyclo-oxygenase-2 expression in chondrocyte/ agarose constructs. Arthritis Res Ther 2008, 10:R35.

29. Chowdhury TT, Bader DL, Lee DA: Dynamic compression inhibits the synthesis of nitric oxide and PGE(2) by IL-1beta-stimulated chondrocytes cultured in agarose constructs. Biophys Res Commun 2001, 285:1168-1174.

30. Das UN: Anti-inflammatory nature of exercise. Nutrition 2004, 20:323-326.

31. Bennell K, Hinmann R: Exercise as a treatment for osteoarthritis. Curr Opin Rheumatol 2005, 17:634-640.

32. Ostrowski K, Rohde T, Asp S, Schjerling P, Pedersen BK: Pro- and antiinflammatory cytokine balance in strenuous exercise in humans. J Physiol 1999, 515:287-291.

33. Rannou F, Poiraudeau S, Revel M: Cartilage: from biomechanics to physical therapy. Ann Readapt Med Physiol 2001, 44:259-267.

34. Lee DA, Bader DL: Compressive strains at physiological frequencies influence the metabolism of chondrocytes seeded in agarose. J Orthop Res 1997, 15:181-188.

35. Lee DA, Knight MM: Mechanical loading of chondrocytes embedded in 3D constructs: in vitro methods for assessment of morphological and metabolic response to compressive strain. Methods Mol Med 2004, 100:307-324.

36. Chowdhury T, Bader DL, Shelton JC, Lee DA: Temporal regulation of chondrocyte metabolism in agarose constructs subjected to dynamic compression. Arch Biochem Biophys 2003, 417:105-111.

37. Lee DA, Brand J, Salter D, Akanji OO, Chowdhury TT: Quantification of mRNA using real-time PCR and Western blot analysis of MAPK events in chondrocyte/agarose constructs. Methods Mol Biol 2011, 695:77-97.

38. Pejchalova K, Krejci P, Wilcox WR: C-natriuretic peptide: an important regulator of cartilage. Mol Genet Metab 2007, 92:210-215.

39. Mericq V, Uyeda JA, Barnes KM, De Luca F, Baron J: Regulation of fetal rat bone growth by C-type natriuretic peptide and CGMP. Pediatr Res 2000, 47:189-193.

40. Suda M, Tanaka K, Yasoda A, Komatsu Y, Chusho H, Miura M, Tamura N, Ogawa Y, Nakao K: C-type natriuretic peptide/guanylate cyclase B system in ATDC5 cells, a chondrogenic cell line. J Bone Miner Metab 2002, 20:136-141.

41. Woods A, Khan S, Beier F: C-type natriuretic peptide regulates cellular condensation and glycosaminoglycan synthesis during chondrogenesis. Endocrinology 2007, 148:5030-5041.

42. Fujishige K, Kotera J, Yanaka N, Akatsuka H, Omori K: Alteration of cGMP metabolism during chondrogenic differentiation of chondroprogenitorlike EC cells, ATDC5. Biochim Biophys Acta 1999, 1452:219-227.

43. Johnson KA, van Etten D, Nanda N, Graham RM, Terkeltaub RA: Distinct transglutaminase 2-independent and transglutaminase 2-dependent pathways mediate articular chondrocyte hypertrophy. J Biol Chem 2003, 278:18824-18832.

44. Chikuda H, Kugimiya F, Hoshi K, Ikeda T, Ogasawara T, Shimoaka T, Kawano H, Kamekura S, Tsuchida A, Yokoi N, Nakamura K, Komeda K, Chung UI, Kawaguchi H: Cyclic GMP-dependent protein kinase II is a molecular switch from proliferation to hypertrophic differentiation of chondrocytes. Genes Dev 2004, 18:2418-2429.

45. Clancy RM, Amin AR, Abramson SB: The role of nitric oxide in inflammation and immunity. Arthritis Rheum 1998, 41:1141-1151.

46. Studer RK, Decker K, Melhem S, Georgescu H: Nitric oxide inhibition of IGF-1 stimulated proteoglycan synthesis: role of cGMP. J Orthop Res 2003, 21:914-921.

47. Geng Y, Zhou L, Thompson WJ, Lotz M: Cyclic GMP and cGMP-binding phosphodiesterase are required for interleukin-1-induced nitric oxide synthesis in human articular chondrocytes. J Biol Chem 1998, 273:27484-27491.

48. Tenor H, Hedbom E, Häuselmann HJ, Schudt C, Hatzelmann A: Phosphodiesterase isoenzyme families in human osteoarthritis chondrocytes: functional importance of phosphodiesterase $4 . \mathrm{Br} J$ Pharmacol 2002, 135:609-618.

49. Morales TI: The insulin-like growth factor binding proteins in uncultured human cartilage: increases in insulin-like growth factor binding protein 3 during osteoarthritis. Arthritis Rheum 2002, 46:2358-2367.

50. I wanaga $\mathrm{H}$, Matsumoto $T$, Enomoto $H$, Okano $\mathrm{K}$, Hishikawa $Y$, Shindo $H$, Koji T: Enhanced expression of insulin-like growth factor-binding proteins in human osteoarthritic cartilage detected by immunohistochemistry and in situ hybridization. Osteoarthritis Cart 2005, 13:439-448.

51. Kaupp UB, Seifert R: Cyclic nucleotide-gated ion channels. Physiol Rev 2002, 82:769-824.

52. Lotz M, Hashimoto S, Kühn K: Mechanisms of chondrocyte apoptosis. Osteoarthritis Cart 1999, 7:389-391.

53. Sugimoto T, Yoshino M, Nagao M, Ishii S, Yabu H: Voltage-gated ionic channels in cultured rabbit articular chondrocytes. Comp Biochem Physiol C 1996, 115:223-232.

54. Mobasheri A, Gent TC, Womack MD, Carter SD, Clegg PD, Barrett-Jolley R: Quantitative analysis of voltage-gated potassium currents from primary equine (Equus caballus) and elephant (Loxodonta africana) articular chondrocytes. Am J Physiol Regul Integr Comp Physiol 2005, 289:R172-R180.

55. Chowdhury TT, Salter DM, Bader DL, Lee DA: Signal transduction pathways involving p38 MAPK, JNK, NFkappaB and AP-1 influence the response of chondrocytes cultured in agarose constructs to IL-1beta and dynamic compression. Inflam Res 2008, 57:306-313.

56. Chowdhury $\Pi$, Knight MM: Purinergic pathway suppresses the release of NO and stimulates proteoglycan synthesis in chondrocyte/agarose constructs subjected to dynamic compression. J Cell Physiol 2006, 209:845-853.

doi:10.1186/ar3459

Cite this article as: Ramachandran et al:: Biomechanical signals and the C-type natriuretic peptide counteract catabolic activities induced by IL$1 \beta$ in chondrocyte/agarose constructs. Arthritis Research \& Therapy 2011 13:R145.

\section{Submit your next manuscript to BioMed Central and take full advantage of:}

- Convenient online submission

- Thorough peer review

- No space constraints or color figure charges

- Immediate publication on acceptance

- Inclusion in PubMed, CAS, Scopus and Google Scholar

- Research which is freely available for redistribution

Submit your manuscript at www.biomedcentral.com/submit
C Biomed Central 